\title{
Species traits reveal effects of land use, season and habitat on the potential subsidy of stream invertebrates to terrestrial food webs
}

\author{
B. G. McKie ${ }^{1}$ - L. Sandin ${ }^{2}$-P. E. Carlson ${ }^{1}$ - R. K. Johnson ${ }^{1}$
}

Received: 11 July 2017 / Accepted: 11 January 2018 / Published online: 19 January 2018

(c) The Author(s) 2018. This article is an open access publication

\begin{abstract}
Adult aquatic insects with a terrestrial life-stage are important vectors transferring resources assimilated in freshwater environments to terrestrial consumers. Research on this linkage has focused particularly on how terrestrial environmental features affect dispersal of adult aquatic insects, and on the responses of terrestrial consumers. However, both the timing and extent of dispersal by adult aquatic insects are further regulated by their species-specific life history traits. We sampled aquatic invertebrates from nine streams in central Sweden, and assessed how the composition of key traits related to dispersal and life history varied between in-stream habitats (riffles, pools), seasons (autumn, spring), and among streams differing in catchment land use (forested, agriculture). Traits indicative of more limited adult dispersal (e.g. small adult size and weak flying strength), along with traits indicative of strongly pulsed peaks in emergence (e.g. univoltinism and well-synchronised emergence) were all more abundant in the agricultural than forested streams in the autumn. However, these differences had disappeared by late spring, possibly reflecting early emergence by the univoltine taxa that dominated the agricultural stream communities and/or elevated mortality in the agricultural streams. Riffles supported higher abundances of insects with strongly flying adults, whereas traits associated with more limited dispersal were characteristic of insect assemblages in pools, which also supported the highest proportion of invertebrates completely lacking an adult flying stage. This result is likely to have implications at larger scales, given the dominance of soft-bottomed pool habitats and scarcity of riffles in many agricultural landscapes. Overall, our analysis indicates that while overall production of aquatic invertebrates with a winged adult was greater in agricultural streams, availability of this productivity for terrestrial consumers is more likely to be spatially restricted closer to the stream channel, and potentially also more temporally pulsed .
\end{abstract}

Keywords Benthic invertebrates - Dispersal traits $\cdot$ Cross ecosystem resource flows $\cdot$ Emerging aquatic insects $\cdot$ Land-use change $\cdot$ Life history traits

\section{Introduction}

The transfer of aquatic resource subsidies into terrestrial food webs via the winged adult stages of aquatic insects is recognized as a key component in the functioning of riverine

Electronic supplementary material The online version of this article (https://doi.org/10.1007/s00027-018-0565-4) contains supplementary material, which is available to authorized users.

B. G. McKie

Brendan.mckie@slu.se

1 Department of Aquatic Sciences and Assessment, Swedish University of Agricultural Sciences, P.O. Box 7050, 75007 Uppsala, Sweden

2 Department of Aquatic Resources, Swedish University of Agricultural Sciences, Stockholm, Sweden networks (Moldenke and Linden 2007; Lamberti et al. 2010; Muehlbauer et al. 2014). Not only do aquatic insects often emerge with very high abundance and biomass, but they also carry nutrients and essential lipids produced within aquatic environments (Baxter et al. 2005; Gratton et al. 2008; Gladyshev et al. 2009; Torres-Ruiz and Wehr 2010). These aquatic insect subsidies support a multitude of organisms in riparian communities, including arthropods (Collier et al. 2002; Burdon et al. 2013), birds (Gray 1993; Poulin et al. 2010) and bats (Fukui et al. 2006). Research is now increasingly 
focussing on understanding how anthropogenic disturbances alter the factors that regulate the production and dispersal of aquatic insect subsidies, and their uptake into terrestrial food webs (Tockner et al. 1999; Petersen et al. 2004; Jonsson et al. 2013; Kautza and Sullivan 2015; Carlson et al. 2016; Greenwood and Booker 2016).

Key factors regulating the incorporation of aquatic subsidies into terrestrial food webs include the timing of adult aquatic insect emergence relative to the resource requirements of terrestrial consumers, the dispersal patterns of adult aquatic insects into the terrestrial environment, and rates of consumption of the aquatic subsidy by terrestrial consumers (Polis et al. 1997; Nakano and Murakami 2001; Marczak et al. 2007). Accordingly, much research attention has focused on how terrestrial environmental features regulate subsidy dispersal and the responses of terrestrial consumers (e.g. forest cover, complexity of ground habitats, availability of terrestrial resources), and on how human activities alter these linkages (Petersen et al. 2004; Greenwood and McIntosh 2008; Marczak and Richardson 2008; Stenroth et al. 2015). However, both the timing and extent of dispersal by adult aquatic insects are further regulated by their species-specific life history traits (Greenwood and Booker 2016). These traits are components of a species' phenotype that regulate when and how often individuals emerge from the aquatic larval to terrestrial adult state (e.g. voltinism, seasonal syncronicity), and how far from the natal stream individuals might disperse (e.g. adult flying strength, flight distance, body size) (Petchey and Gaston 2006; Truchy et al. 2015; Greenwood and Booker 2016), and which thereby influence their availability as resource subsidies to terrestrial consumers in time and space (Table 1).

Anthropogenic disturbances can have particularly strong effects on the species trait composition of freshwater macroinvertebrate communities (e.g. Frainer and McKie 2015). Significantly, species traits are not independent entities, but because of ecological and evolutionary trade-offs involved in life-history strategies (Verberk et al. 2008) are often linked into clusters or "syndromes", i.e., a group of tightly linked traits strongly associated with particular genera or families (Reich et al. 2003; Poff et al. 2006). Indeed, communities dominated by smaller, short-lived organisms with more flexible life cycles and generalist feeding behaviours often dominate human impacted streams (Statzner and Béche 2010), as species with these characteristics are favoured under the more extreme and less certain environmental conditions of degraded habitats. Human impacts on the composition of linked dispersal and life history traits thus need to be incorporated into a broader framework for understanding variation in how aquatic insects subsidize terrestrial food webs.

The potential for land use effects on the composition of aquatic invertebrate communities to alter the composition of dispersal related traits is seen in research by Muehlbauer et al. (2014), who found that greater stream-to-land subsidy distances were partly explained by the presence of longer lived and/or stronger flying taxa. Similarly, Carlson et al. (2016) found that dispersal distances of adult aquatic insects were longer when abundances of blood-feeding taxa (which disperse widely in search of food) were higher, although the bulk of variation in dispersal distances was explained by characteristics of the terrestrial abiotic environment (wind, insolation etc). However, Carlson et al. (2016) focussed mainly on the summer months, and their sampling method was biased towards capturing the relatively small sized and weak flying adults of aquatic Diptera. Accordingly, their study under-estimated occurrence of key species traits that might strongly regulate the quantity of aquatic productivity exported from streams into terrestrial habitats, including (1) larger-sized and stronger flying taxa, (2) species emerging early in the spring and (3) species completely lacking an adult flying stage. One approach for gaining insight into the importance of these shortcomings is through analysis of the composition of dispersal and life history traits present within benthic invertebrate assemblages.

Here, we analyse the functional trait composition of benthic invertebrate assemblages sampled during the same period as Carlson et al's (2016) study, to assess how the dispersal and life history of stream invertebrates are affected by agricultural land use, and how these changes are further moderated by in-stream habitat characteristics and seasonal variation. Samples were taken on two occasions: midAutumn, to capture the trait composition of the complete assemblage following oviposition of adult females the previous summer/early Autumn, and in late spring, following the early spring emergence peak characterising several taxa in boreal regions. We characterized the species trait composition of benthic invertebrates (Table 1) from both agricultural and reference forested streams in order to assess the predictions that (1) invertebrates without a winged adult are more abundant in agricultural streams (Woodward et al. 2012; Burdon et al. 2013) and (2) that insect communities in agricultural streams are overall characterized by traits typical of human impacted systems (Statzner and Beche 2010) associated with reduced dispersal (smaller body size, weaker flying strength) and more constant subsidy availability throughout the season (faster and multivoltine life-cycles, and greater life-history flexibility).

\section{Materials and methods}

\section{Study area and sites}

The nine study streams were situated in central Sweden and were chosen to represent two major land-use typesforest versus agriculture (Table 2). Preliminary land use 
classifications based on GIS information extracted from the Corine land cover database (http://sia.eionet.europa.eu/ CLC2000) were confirmed during reconnaissance prior to the first sampling period in Autumn 2009. At a whole catchment scale, the extent of agricultural land use varied widely for the agricultural streams (from 8 to $43 \%$ ), but in the forested sites was never greater than $1 \%$ (Table 2). The contrast in land use was clear close to the stream channel, based on an in situ characterisation of the riparian zone across a $100 \mathrm{~m}$ corridor on both sides of each stream adjacent to a $100 \mathrm{~m}$ sample reach (Table 2). The forested streams had 93-98\% forest in this zone, whilst the agricultural streams had 40-95\% agricultural fields (predominantly used for barley or pasture). Width of the riparian vegetation at the individual sampling reaches also differed between the two groups: average widths of riparian vegetation for the four agricultural streams ranged from 5 to $34 \mathrm{~m}$, whereas the forested streams flowed through extensive woodland, extending well over $100 \mathrm{~m}$ from the stream channel. These differences in forest cover are primarily attributable to land use-all stream sites occur at low to very low altitudes in a region that historically were forest covered, prior to the development of agriculture (Myrdal and Morell 2011).

The streams were all lowland $(<191 \mathrm{~m}$ a.s.l.), smallmedium sized (Strahler order 2-4, 1.4-10.6 m average stream width at the sampling reach), and shallow (0.1-1.1 m average depth), with circumneutral to slightly alkaline $\mathrm{pH}$ (pH 6.3-8.3, conductivity $2-65 \mathrm{mS} \mathrm{cm}^{-1}$ ), and had a total organic carbon (TOC) content of $15-52 \mathrm{mg} \mathrm{L}^{-1}$. Nutrient concentrations varied from very low to high, depending on the land use classification (Table 1). There were no significant differences in neither the wetted width nor depth between our forested and agricultural stream reaches (Carlson et al. 2016). Further details of in-stream habitats and water chemistry, including chemistry sampling protocols, are included in Carlson et al. (2013).

\section{Invertebrate sampling}

Benthic invertebrate assemblages were quantitatively sampled in mid-autumn 2008 (21 October-5 November) and late Spring 2009 (19 May-1 June) from one pool and riffle habitat per stream. Three replicate samples were collected from each pool and riffle habitat using a $40 \mathrm{~cm}$ high, $500 \mu \mathrm{m}$ mesh Hess sampler covering a bottom area of $0.086 \mathrm{~m}^{2}$ (Wildlife Supply Company http://www.wildco.com). Collected organisms were preserved in the field in $70 \%$ ethanol and returned to the laboratory, where they were sorted from debris. This was achieved by first spreading the sample across a tray divided into 12 grid squares (demarcated through use of a metal grid), and then randomly selecting grid squares from which all individuals were sorted, until 300 individuals in total were retrieved (the last sampled grid square was always

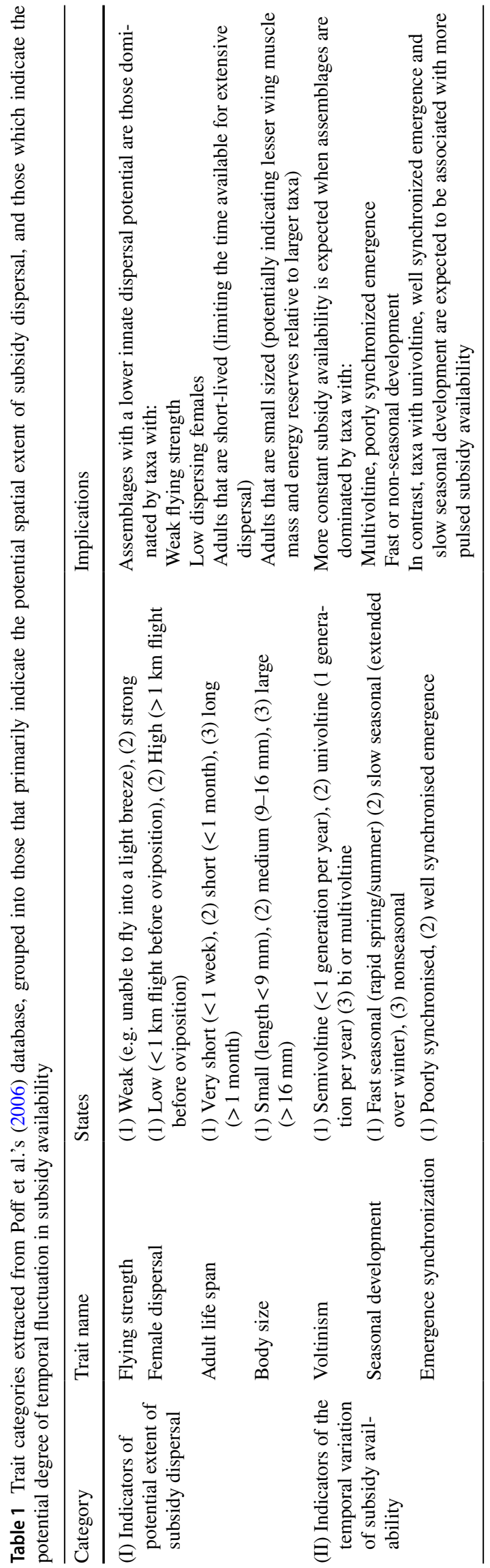




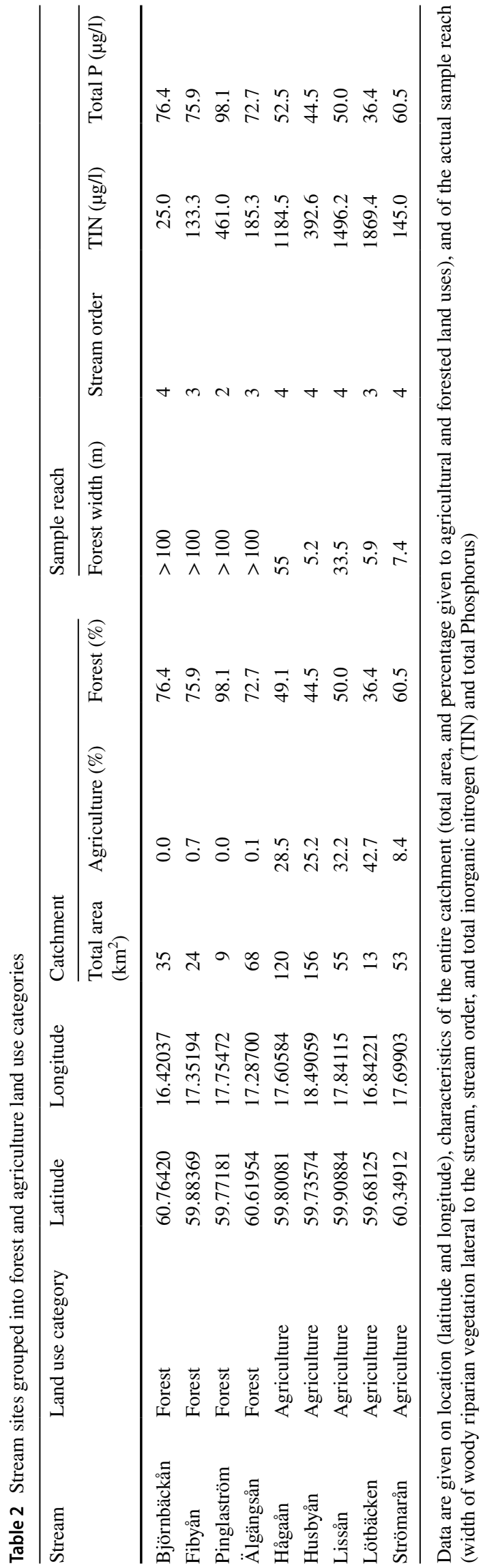

sorted to completion). The remainder of the sample was scanned for large, rare taxa not present in the subsample. All individuals were identified to the lowest possible level of taxonomic resolution (mainly to species and genus, but Chironomidae, Simuliidae and Oligochaeta were sorted to family or order level), and counted.

\section{Characterization of species traits}

We extracted trait information from the database of Poff et al. (2006) for the 105 taxa (out of 140 total) identified from the samples with a winged adult stage. This database was developed for North American genera but we have successfully used it in an earlier study of Swedish stream invertebrates (Göthe et al. 2013), and it is particularly appropriate for this study since it includes a wide selection of traits related to adult dispersal and life histories. Taxa were scored for two broad groups of traits (Table 1): (1) traits that are indicative of the likely extent of adult dispersal, and (2) life history traits which are indicative of seasonally pulsed adult emergence. We emphasise that in focussing on these traits we are not intending to make inferences about the actual extent of aquatic subsidy production and dispersal adjacent to our stream channels, but rather about innate differences in the dispersal potential of our assemblages, and in the seasonality of subsidy availability to terrestrial consumers. Use of these traits yielded in total 18 states (2-3 trait states for each of the seven traits, Table 1).

\section{Statistical analyses}

We tested for differences in the abundances of invertebrates with and without a winged adult stage using a split plot analysis of variance (ANOVA) run with the proc mixed routine in SAS Release 9.3 statistical software (SAS Institute Inc. 2011). Land use (forested versus agriculture), habitat (pool versus riffle) and season (autumn versus spring) were fitted as fixed effects. In order to directly contrast habitats and land use between the two sampling periods, we chose to fit season as a fixed rather than random factor in our ANOVA models, while acknowledging that details of these responses may have differed in other years with different seasonal trajectories. Stream was fitted as a random factor, with the eight streams used as replicates for testing the effects of land use (four replicates per category). All other fixed factors and interactions were tested against error terms incorporating the stream block factor (see Table 2), which were estimated using restricted maximum likelihood (REML). Square-root or log transformation was applied to satisfy assumptions of linearity and constant variance prior to all ANOVAs.

The main clusters of traits occurring across our streams were graphically visualised using nonmetric multidimensional scaling (nMDS), based on square root transformed 
trait abundance data (i.e. number of individuals possessing a given trait and where each trait is treated as a "species" in the analysis) from each stream. This analysis was conducted using the vegan routine in the $\mathrm{R}$ statistical software (R Development Core Team 2012) Release 3.0, based on the Bray-Curtis similarity index.

Our analysis of differences in trait composition among land-use, habitat and season categories was conducted in two steps. First, we conducted an overall test for differences in the multivariate composition of functional traits in our assemblages among land use, seasons and habitats based on a permutational multivariate analysis of variance (perMANOVA), using the procedure "adonis" in the R package vegan (Oksanen et al. 2013). This was followed by univariate tests for variation in the abundances of specific traits, selected to represent the main trait clusters and to help address our specific hypotheses. No general post hoc adjustment of significance levels was implemented for these tests, since they were not conducted for every possible trait, and were designed to address specific a priori hypotheses (Quinn and Keough 2002). We chose to analyse the most strongly contrasting states for each of the selected traits, in order to assess the most marked shifts in subsidy dispersal and pulse indicators between our land use, habitat and season categories (Table 1). The perMANOVA was based on Euclidean distances, so that both the multivariate and univariate tests were based on metric data, but outcomes of statistical tests for the perMANOA were identical regardless of whether Euclidean or Bray-Curtis similarities were used. Both the perMANOVA and univariate ANOVAs used the same random effect error structure as described above for the tests of invertebrates with and without a winged adult stage.

\section{Results}

\section{Variation in invertebrates with and without an adult flying stage}

Differences between habitats, seasons and land use categories were overall similar for the total abundances of benthic invertebrates both with and without an adult flying stage (Fig. 1). Abundances were greater in agricultural than forested streams (ANOVA both $\mathrm{F}_{1,7}>14.48, \mathrm{p}<0.006$ ), but
Fig. 1 Total abundance per square meter of stream substrate (mean \pm SE) of benthic invertebrates without $(\mathbf{a}, \mathbf{c})$ and with (b, d) a winged adult life stage sampled in autumn and spring in forested and agricultural streams, pooling across habitats (a, b) and sampled from riffle and pool habitats, pooling across seasons and land use categories $(\mathbf{c}, \mathbf{d})$ (a) No adult flying stage

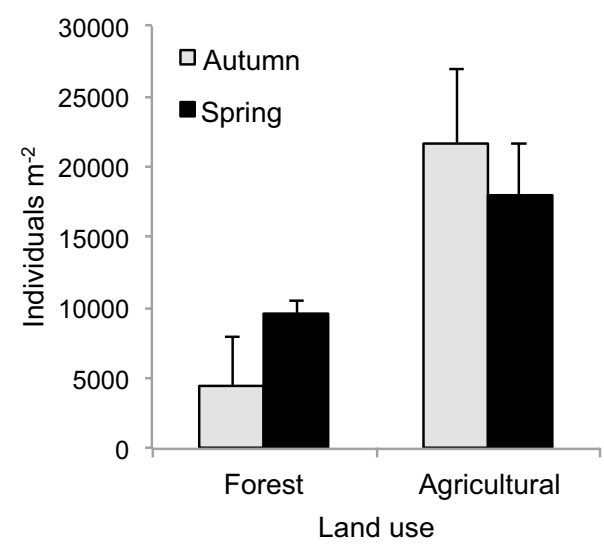

(c) No adult flying stage

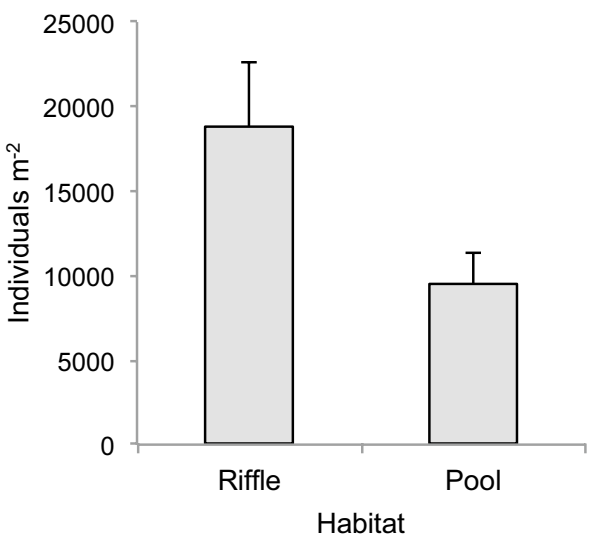

(b) Adult flying stage

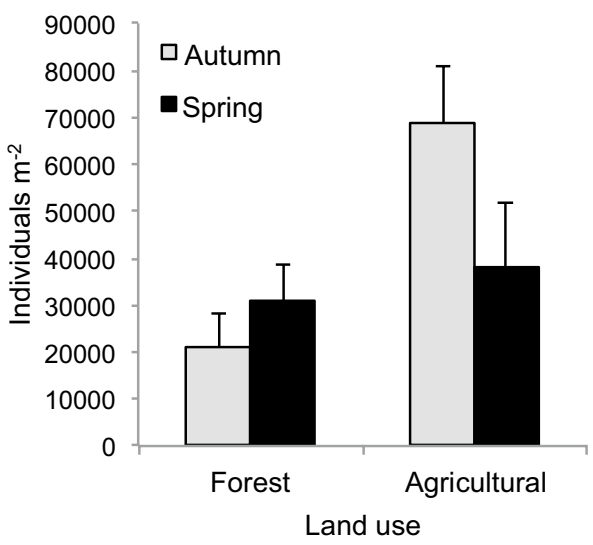

(d) Adult flying stage

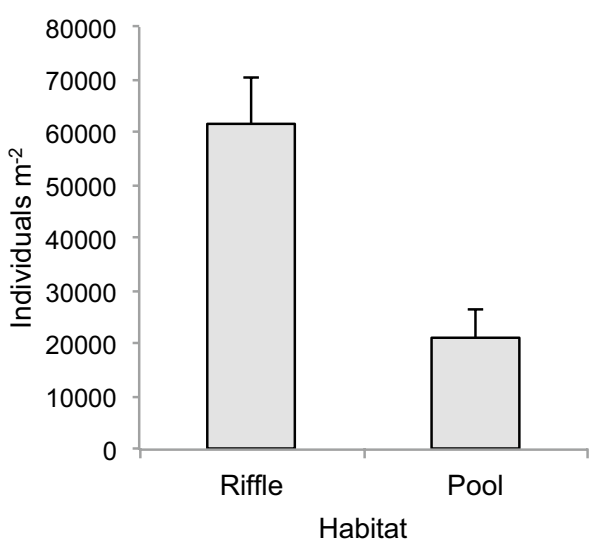


an interaction was also apparent between land use and season (both $\mathrm{F}_{1,7}>6.08, \mathrm{p}<0.048$ ), with the difference in total abundance between agricultural and forested streams reduced in the spring compared to the autumn (Fig. 1a, b). Abundances were also higher in riffle than pool habitats (both $\mathrm{F}_{1,7}>6.08, \mathrm{p}<0.043$ ) for both invertebrate groups (Fig. 1c, d). No other main effects or interactions were significant (all $\mathrm{F}_{1,7}<4.1, \mathrm{p}>0.083$ ).

\section{Trait clusters in multivariate space}

The graphical representation of co-occuring traits, based on our nMDS analysis, is shown in Fig. 2. For clarity, traits that were overlaid with one another in multivariate space, reflecting strong associations particular taxonomic groups, are identified as trait clusters in Fig. 2. Cluster A comprised semivoltine taxa with a non-seasonal development and long adult life span (taxa in this group were all river beetles, e.g., Elmis aenea, Limnius volckmari and Oulimnius sp.), while cluster B included taxa with short adult life span, medium size at maturity, slow seasonal development, and poorly synchronized emergence (taxa in this group were large dipterans such as Dicranota sp., Ptychoptera sp., and Tipula sp.). Trait cluster $\mathrm{C}$ included taxa with a small size at maturity, very short adult life span, fast seasonal development, and well synchronized emergence (typical taxa in this group were stoneflies such as Amphinemura sp., Leuctra sp., and Nemoura sp, as well as the small non-biting midge taxa Orthocladiinae, Tanypodinae, and Chironomini). Cluster D included univoltine taxa with high female dispersal and weak adult flying strength (typical taxa were caddisflies such as Athripsodes sp., Mystacides sp., and Polycentropus sp., as well as non-biting midges such as Orthocladinae, Prodiamesa olivacea, and Tanypodinae). One abundant taxa, Simuliidae (comprising 82,084 individuals, or $16 \%$ of all individuals sampled), was intermediate between clusters $\mathrm{C}$ and D, with small adult size and very short adult life span, but also long female dispersal.

Trait cluster (E) was characterized by bi- and multivoltine taxa with low female dispersal (almost exclusively mayflies such as Baetis sp., Centroptilum sp., and Caenis luteola), while cluster $\mathrm{F}$ included taxa with a large size at maturity (caddisflies such as Halesus sp., Limnephilus sp., and Potamophylax sp., as well as dragonflies and damselflies such as Calopteryx sp., Somatochlora metallica, and Libellulidae). A further single trait defined cluster G: taxa with a strong adult flying strength (mainly consisting of beetles such as Dytiscidae, Haliplus sp., and Platambus maculatus, and dragon- and damselflies such as Libellulidae, Calopteryx sp., and Somatochlora metallica).

\section{Trait composition: differences between land use and habitat categories}

Trait composition based on abundances differed between land use categories (perMANOVA $\mathrm{F}_{1,28}=6.54, \mathrm{p}=0.021$ ), and between habitats $\left(\mathrm{F}_{1,28}=13.556, \mathrm{p}<0.001\right)$, with an additional interaction between land use and season $\left(\mathrm{F}_{1,28}=4.348, \mathrm{p}=0.035\right)$ indicating temporal shifts in the relative proportions of different types of traits in the forested and agricultural habitats. Among these three terms, the proportion of variance explained was highest for habitat $\left(r^{2}=0.24\right)$, followed by land use $\left(r^{2}=0.12\right)$ and then the land use by season interaction $\left(r^{2}=0.08\right)$. No other main effects or interactions were significant in perMANOVA analyses of trait abundances.

Follow-up analysis of variance of individual traits indicate that the seasonal shift in trait composition between forested and agricultural sites was mainly related to variation in the abundances of traits associated with trait clusters $\mathrm{C}$ and D (Table 3; Fig. 2). These are mostly traits associated with limited dispersal capacity (very short adult life span, weak adult flying strength and small adult size) and with life
Fig. 2 Nonmetric multidimensional scaling of square root transformed trait abundances. Letters A-G denote clusters of traits where each cluster contains several closely overlaid traits, reflecting strong associations with the highlighted taxa

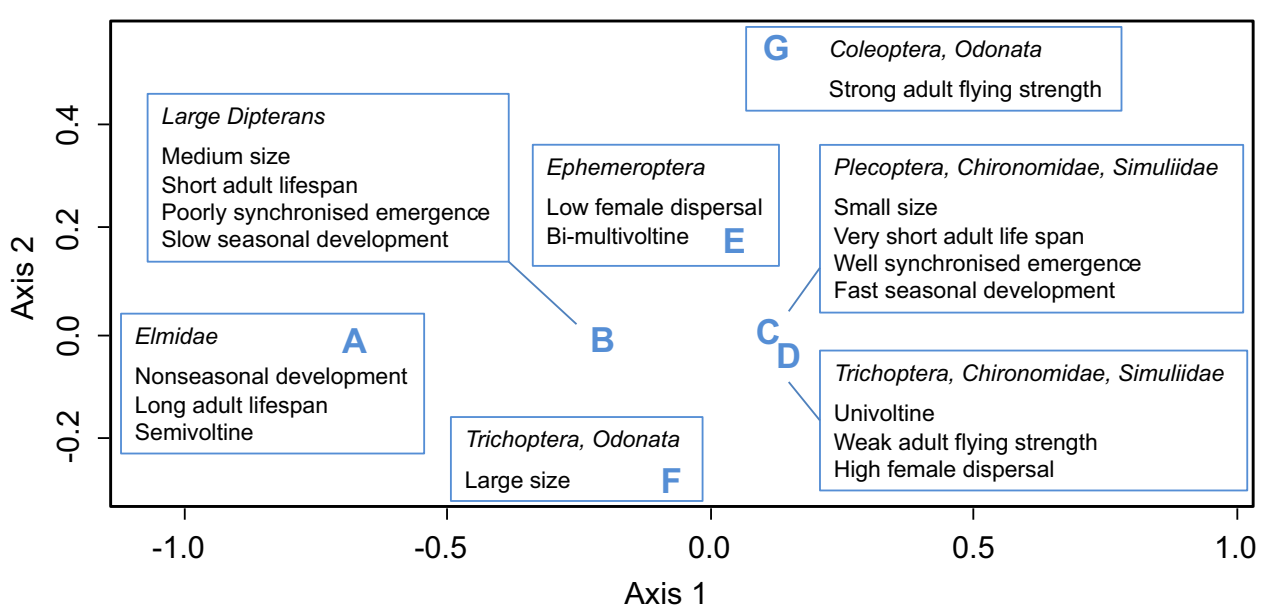

Axis 1 
Table 3 Results of mixed model ANOVA test of land-use type, habitat, and season on abundance data of the seven benthic invertebrate traits

\begin{tabular}{|c|c|c|c|c|c|c|c|c|c|c|c|c|c|c|c|c|}
\hline \multirow[b]{2}{*}{ Factor } & \multicolumn{2}{|c|}{$\begin{array}{l}\text { Weak flying } \\
\text { strength }\end{array}$} & \multicolumn{2}{|c|}{$\begin{array}{l}\text { Strong flying } \\
\text { strength }\end{array}$} & \multicolumn{2}{|c|}{$\begin{array}{l}\text { Low female } \\
\text { dispersal }\end{array}$} & \multicolumn{2}{|c|}{$\begin{array}{l}\text { High female } \\
\text { dispersal }\end{array}$} & \multicolumn{2}{|c|}{$\begin{array}{l}\text { Very short } \\
\text { adult life }\end{array}$} & \multicolumn{2}{|c|}{$\begin{array}{l}\text { Long adult } \\
\text { life }\end{array}$} & \multicolumn{2}{|c|}{ Small size } & \multicolumn{2}{|c|}{ Large size } \\
\hline & $\mathrm{F}$ & $\mathrm{p}$ & $\mathrm{F}$ & $\mathrm{p}$ & $\mathrm{F}$ & $\mathrm{p}$ & $\mathrm{F}$ & $\mathrm{p}$ & $\mathrm{F}$ & $\mathrm{p}$ & $\mathrm{F}$ & $\mathrm{p}$ & $\mathrm{F}$ & $\mathrm{p}$ & $\mathrm{F}$ & $\mathrm{p}$ \\
\hline Land use & 9.6 & 0.017 & 2.5 & n.s & 4.7 & n.s & 4.9 & n.s & 9.3 & 0.018 & 0.6 & n.s & 22.2 & 0.002 & 1.3 & n.s \\
\hline Habitat & 15.1 & 0.006 & 84.7 & $<0.001$ & 74.3 & $<0.001$ & 7.0 & 0.033 & 32.6 & 0.001 & 20.1 & 0.003 & 42.8 & $<0.001$ & 0.3 & n.s \\
\hline Season & 1.4 & n.s & 0.2 & n.s & 0.6 & n.s & 0.7 & n.s & 0.3 & n.s & 5.2 & n.s & 0.4 & n.s & 0.2 & n.s \\
\hline $\mathrm{LxH}$ & 0.0 & n.s & 0.1 & n.s & 0.7 & n.s & 0.0 & n.s & 1.1 & n.s & 0.6 & n.s & 0.7 & n.s & 1.3 & n.s \\
\hline $\mathrm{SxH}$ & 3.9 & n.s & 0.1 & n.s & 1.8 & n.s & 1.0 & n.s & 0.8 & n.s & 0.0 & n.s & 0.9 & n.s & 10.6 & 0.014 \\
\hline LxS & 9.9 & 0.016 & 3.3 & n.s & 1.9 & n.s & 6.6 & 0.037 & 8.0 & 0.026 & 0.0 & n.s & 7.5 & 0.029 & 0.1 & n.s \\
\hline LxSxH & 3.7 & $\mathrm{n} . \mathrm{s}$ & 2.7 & n.s & 3.8 & n.s & 3.1 & n.s & 3.3 & n.s & 0.0 & n.s & 3.7 & n.s & 0.4 & n.s \\
\hline
\end{tabular}

$F \mathrm{~F}$ ratio, $p \mathrm{p}$ value. All tests conducted using 1 numerator against 8 denominator degrees of freedom. Tests significant at $\mathrm{p}<0.05$ are highlighted in bold

histories characterised by strong emergence pulses (highly synchronised emergence, fast seasonal development and univoltine life histories). All these traits were affected not only by land use, but also by a significant interaction between season and land use (Table 3), with abundances much greater in agricultural streams in the autumn but not spring (Fig. 3a). Only one trait indicating greater dispersal ability showed a similar pattern of response: with greater female dispersal distance substantially more abundant in agricultural streams in the autumn but not spring (Fig. 3b). In contrast, traits associated with the remaining categories and reflecting either greater adult dispersal category (e.g. long adult life, strong adult flying strength, larger body size) and less synchronised emergence pulses (e.g. poorly synchronised emergence and bi- or univoltine life histories), were not affected either by land use or any interaction between land use and season (Table 3).

Almost all traits were more abundant in riffles than pools overall (Table 3; Fig. 4a, b). The exception was large adult size (representing trait Cluster F), which was affected by an interaction between habitat and season (Table 2). Large body size abundances were greater in pools than riffles in the autumn, but differed little between habitats in the spring (Fig. 4c). Finally, a three-way interaction between season, land use and habitat was apparent for univoltine insects (Table 3). Abundances of univoltine insects were higher in riffle than pool habitats in forest streams in both autumn and spring, but in agricultural streams this difference was only apparent in the spring (Fig. 4d).

\section{Discussion}

Abundances of all invertebrates, including those both with and without a terrestrial flying adult stage, were higher overall in agricultural than forested streams. This likely reflects higher autotrophic productivity associated with reduced shading and increased nutrient inputs in agricultural streams (Delong and Brusven 1998; Harding et al. 1999), particularly given there were no differences in the overall size of the two stream types (Carlson et al. 2016). Abundances of most of our focal species traits were similarly higher in the
Fig. 3 Effect of land use and season on abundances per square meter of stream substrate of individuals (mean \pm SE) with representative traits indicating a limited dispersal (weak adult flying strength) and $\mathbf{b}$ greater dispersal capacity (high female dispersal). Other traits showing the same pattern of variation with land use and season were very short $(<1$ week) adult life span, small adult body size, synchronized emergence, univoltine life histories (Table 2) (a) Weak flying strength

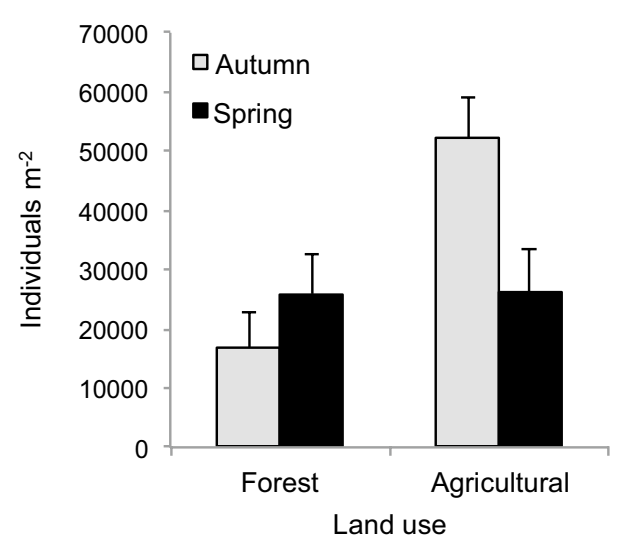

(b) High female dispersal

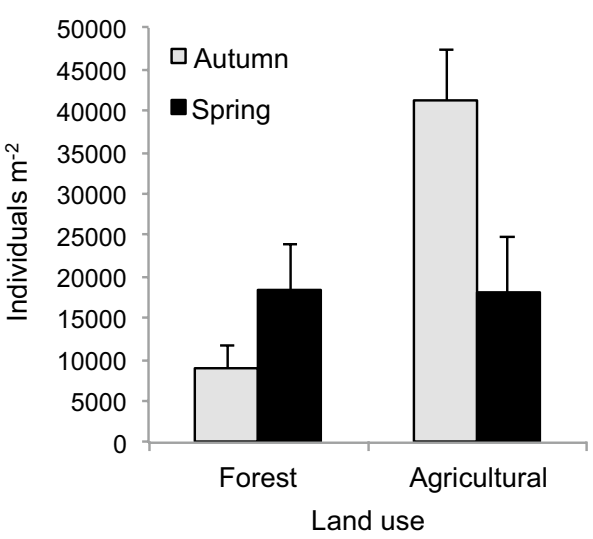


Fig. 4 Effect of habitat on abundances per square meter of stream substrate of individuals $($ mean $\pm \mathrm{SE})$ with representative traits indicating a limited dispersal (weak adult flying strength) and $\mathbf{b}$ greater dispersal capacity (strong adult flying strength); interactions between habitat and season on $\mathbf{c}$ large body size, and between habitat, season and land use (For Forest, Agr Agricultural) on d univoltine life histories (a) Weak flying strength

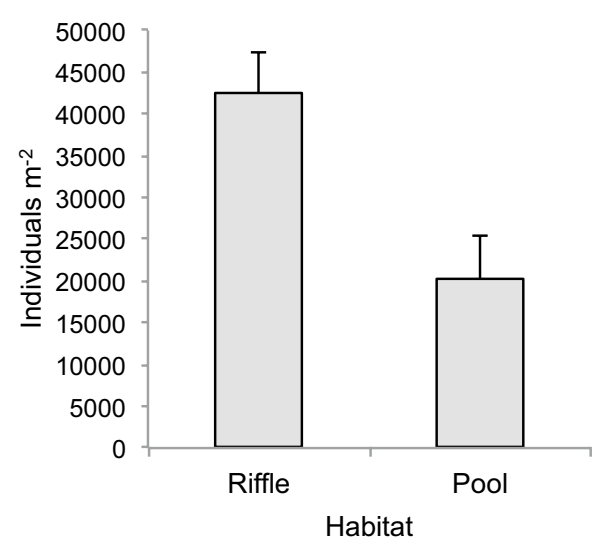

(c) Large adult body size

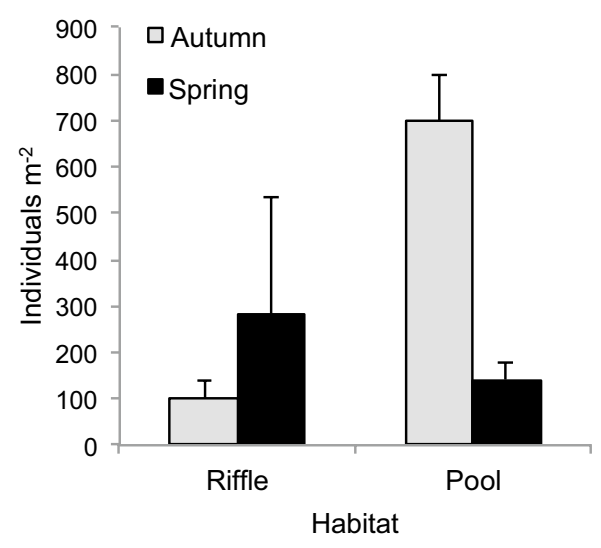

(b) Strong flying strength

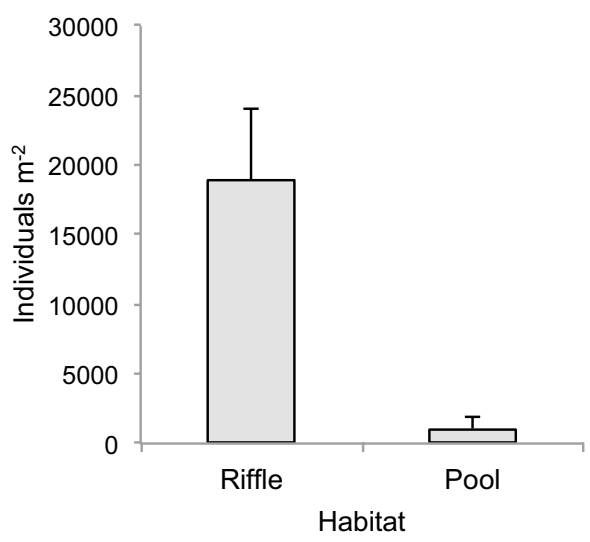

(d) Univoltine life history

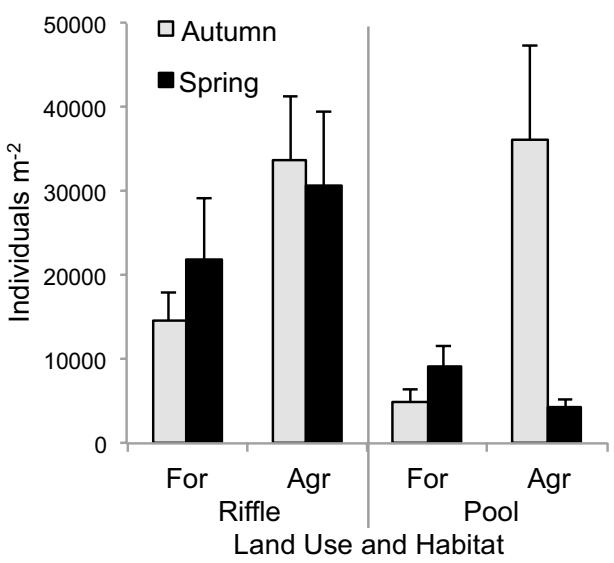

agricultural streams, and in riffle habitats. However, we also observed multiple interactions between land use, season and habitat, both in our analyses of all traits combined, and when analysing individual traits separately. These interactions reflect differences in the predominant life history strategies characterising the macroinvertebrate communities of forested and agricultural streams, and of riffle and pool habitats, and have implications for potential spatio-temporal variability in aquatic subsidy production and availability for terrestrial consumers.

Most of the traits characterising aquatic insect assemblages from the agricultural streams are indicative of more limited dispersal by the adult stages, including small adult size, short adult life span and weak adult flying strength. These traits were associated especially with small-sized Diptera having short-lived adults, particularly Chironomidae, which dominated our agricultural assemblages. Individuals characterized by these traits will generally stay close to the stream edge following emergence, and their short adult life span will both limit the time available both for extensive dispersal, and for consumption by terrestrial consumers (Kovats et al. 1996; Malmqvist 2002; Petersen et al. 2004;
Krosch et al. 2009). Greenwood and Booker (2016) similarly found that small body size was a characteristic trait of invertebrate assemblages from streams with more pasture upstream, though this was associated with strong rather than poorly dispersing taxa. In our study, only one trait indicative of greater dispersal, long female flight distances, was characteristic of the agricultural streams, associated with blood-feeding Diptera (Ceratopogonidae and Simuliidae) that have females which disperse farther in search of meals (Lassen et al. 2012; McCreadie and Adler 2012). The influence that this might have on connectivity between freshwater and terrestrial habitats is demonstrated by Carlson et al.'s (2016) finding that the proportion of blood feeding Ceratopogonidae was associated with greater dispersal distance by adult Diptera overall.

Apart from small body size and short adult life spans, the agricultural stream assemblages were further characterised by traits indicative of strongly pulsed peaks in emergence, including univoltinism and well-synchronised emergence. This was in contrast with our hypotheses, but reflects the dominance of our assemblages by univoltine Diptera. Strongly synchronised and discrete pulses in subsidy 
availability may allow more mobile terrestrial consumers (e.g. birds, bats) to similarly synchronise temporal patterns of habitat and resource consumption according to subsidy availability [e.g. moving closer to stream habitats during periods of peak subsidy availability (Fukui et al. 2006)]. However, while these traits were substantially more abundant in the agricultural than forested streams in the autumn, these differences were not apparent in the spring. This might indicate that a large proportion of these univoltine species had already emerged by the time our second survey was conducted in late spring-early summer (Tokeshi 1994). Alternatively, predation pressure impacting the most abundant taxa (e.g. Worischka et al. 2015) might also have differed between the stream types during the intervening winter season, with benthivorous fish notably abundant in three of the agricultural streams (227-683 individuals from a quantitative electrofishing survey), compared with the forested streams (0-86 individuals) (P.E. Carlson, unpublished data). Earlier emergence might even be triggered as a phenological response to the presence of predators, allowing vulnerable immature insects to escape exposure to predation in the aquatic environment (Moore and Schindler 2010). These alternative explanations have strongly contrasting implications for the availability of aquatic subsidy to terrestrial consumers. If the decline in insect and trait abundances in the agricultural streams between autumn and spring predominantly reflects a spring-time emergence peak, then this suggests a more pronounced pulse of adult aquatic insect subsidy is available to terrestrial consumers along agricultural than forest streams early in the season. In contrast, elevated mortality in the agricultural streams would limit the amount of aquatic subsidy ultimately exported as adult insects, despite the overall higher productivity of these systems.

Traits that did not differ with land-use included large size at maturity and a longer adult life span, along with poorly synchronised emergence. A greater life span increases the time available for longer dispersal, and/or the time available for consumption by terrestrial consumers, and poorly synchronised emergence is also indicative of a more extended supply of subsidy to terrestrial consumers. Large body size is an indicator of stronger flying strength, and the availability of both larger sized and smaller sized subsidy might allow for optimal feeding across a broader size range of terrestrial consumers (Brose et al. 2008). Our finding that longer-lived, larger sized and stronger flying taxa did not differ between forested and agricultural streams emphasises the need to quantify as biomass how much aquatic subsidy these taxa export, compared with much more abundant but weaker flying smaller taxa (Stenroth et al. 2015). Significantly, most of the taxa associated with these traits were almost entirely absent in the survey of adult flying insects conducted by Carlson et al. (2016), possibly because these taxa are either too large and strong, or fly too high, to be routinely trapped by their sticky trap sampling method. It is not known whether dispersal of these taxa is inhibited to the same extent in agricultural landscapes as observed for smaller sized and weak flying Diptera (Carlson et al. 2016), though Stenroth et al. (2015) notably found that adults of larger sized aquatic taxa were more associated with forested than agricultural streams.

Overall abundances of aquatic invertebrates, and of most of the aquatic insect traits, were higher in the riffle than pool habitats. A higher number of individuals in riffle versus pool habitats were also found in all studies evaluated in a review of the fauna of these two habitat types (Logan and Brooker 1983), and may reflect higher oxygenation concentrations and light penetration in the shallow, fast flowing waters, favouring greater biological activity and secondary production (Rosenfeld and Hudson 1997). Insects with a large body size (mostly Trichoptera) were more abundant in pools, but only in the autumn, suggesting an early emergence peak of these organisms. We also found that the proportion of invertebrates without an adult flying stage were higher in pools than riffles (mostly Oligochaeta and Bivalvia), while insects with strong flying adults (Coleoptera and Odonata) were more abundant overall in riffles. Thus, invertebrate production in pools is dominated by taxa with a limited capacity to subsidize terrestrial food webs, whilst riffles appear to have a particularly important role in supporting some of the most strongly dispersing adult aquatic insects.

Our analyses confirm that agricultural streams support higher benthic invertebrate abundances per square meter than forested streams, and that much of this productivity is likely to be retained in biomass of invertebrates lacking an adult stage (Burdon et al. 2013), or exported as smaller and weaker flying adult insect taxa (Greenwood and Booker 2016; Carlson et al. 2016). However, if the decline in these less dispersive insects in the spring agricultural samples is attributable to early emergence, then this might indicate that a large proportion of the total subsidy produced in agricultural streams becomes available to terrestrial consumers early in the season. This might be particularly valuable for breeding birds, which are capable of flying from nesting sites to feed alongside productive agricultural streams, but might be less beneficial for terrestrial consumers that have their peak productivity later in the season (Uesugi and Murakami 2007; Marczak and Richardson 2008; Strasevicius et al. 2013; Sato et al. 2016). Furthermore, differences in the types of traits characterising adult aquatic insect assemblages among our habitat, season and land use categories have implications for the functioning of terrestrial ecosystems extending beyond the supply of aquatic subsidy. This includes the extent to which adults feed in the terrestrial environment (Wesner 2010), for example as predators (Odonata) which may strongly select particular prey types (Duong 
et al. 2017), or bloodsuckers (Simuliidae, Ceratopogonidae) potentially transmitting parasites (Malmqvist et al. 2004), or as nectar feeders only, as seen in some chironomids, which might have a role in pollination (Armitage 1994). Finally, the short adult life spans of the aquatic taxa dominating the agricultural assemblages might limit the time available for each prey item to be consumed by terrestrial consumers, resulting in the deposition of large quantities of dead insects on the ground, pointing to the need for more research into how aquatic insects subsidise decomposing organisms in soil based food webs (Collier et al. 2002; Hoekman et al. 2011; Dreyer et al. 2012).

Riffle habitats were notable in our study for supporting more strongly dispersing invertebrates with a winged adult life stage, and thus may be particularly important in supporting the transfer of matter and energy from aquatic to terrestrial ecosystems. At a landscape scale, the spatial distribution of riffles and pools among different streams can vary substantially (Gratton and Vander Zanden 2009). Agricultural streams are often strongly modified relative to forested sites in the same region, reflecting both hydromorphological changes arising from losses of riparian vegetation, and direct anthropogenic modification of channel forms, e.g. dredging and agricultural channelization (Burcher et al. 2007), with these impacts particularly prominent in our study region in central Sweden. These modifications often result in a stream profile characterised by long pool sequences separating short riffle sequences without meanders (Petersen 1992), in contrast with the more regular pool-riffle sequence which characterizes many more natural systems flowing through forest (Leopold et al. 1964; Frainer et al. 2014). This contrast was apparent in our study, where riffle habitats were very rare and short in length in the agricultural streams (pers obs), whereas in the forested streams, there was a more even distribution between pool and riffle habitats. This implies that the overall reduction in traits associated with stronger dispersal at local scales within our agricultural study reaches is likely to be further strengthened by the overall decline in riffle habitats in agricultural landscapes. Accordingly, restoration of riffle habitats in agricultural streams, when linked with protection of riparian buffer zones, may have particular value in strengthening aquatic-terrestrial linkages (e.g. Kupilas et al. 2016; Frainer et al. 2018).

Acknowledgements We thank Órla McLaughlin and several anonymous referees, all of whom provided insightful comments that helped improve the manuscript. Leonard Sandin was funded by the Marie Curie Actions of the European Commission (FP7-2010-PEOPLE-IEF) through the FRESHCLIM project (Project no. 273215) and the EU REFORM project (Grant Agreement no. 282656) as well as by an individual grant from the Aarhus University Forskningsfond (AUFF-2010FLS-6-44). Additional financial support was provided to BGM through the 2015-2016 BiodivERsA COFUND call for research proposals, with the national funders FORMAS (dnr 2016-1945) and the Swedish
Environmental Protection Agency. We are most grateful to Lars Eriksson and Magda-Lena Wiklund-McKie for expert macroinvertebrate identification

Open Access This article is distributed under the terms of the Creative Commons Attribution 4.0 International License (http://creativecommons.org/licenses/by/4.0/), which permits unrestricted use, distribution, and reproduction in any medium, provided you give appropriate credit to the original author(s) and the source, provide a link to the Creative Commons license, and indicate if changes were made.

\section{References}

Armitage P (1994) Behaviour and ecology of adults. In: Armitage P, Cranston PS, Pinder LCV (eds) Chironomidae: biology and ecology of non-biting midges. Chapman and Hall, London, pp 194-224

Baxter CV, Fausch KD, Saunders WC (2005) Tangled webs: reciprocal flows of invertebrate prey link streams and riparian zones. Freshw Biol 50:201-220

Brose U, Ehnes R, Rall B, Vucic-Pestic O, Berlow E, Scheu S (2008) Foraging theory predicts predator-prey energy fluxes. J Anim Ecol 77:1072-1078

Burcher C, Valett H, Benfield E (2007) The land-cover cascade: relationships coupling land and water. Ecology 88:228-242

Burdon FJ, McIntosh AR, Harding JS (2013) Habitat loss drives threshold response of benthic invertebrate communities to deposited sediment in agricultural streams. Ecol Appl 23:1036-1047

Carlson PE, Johnson RK, McKie BG (2013) Optimizing stream bioassessment: habitat, season, and the impacts of land use on benthic macroinvertebrates. Hydrobiologia 704:363-373

Carlson PE, McKie BG, Sandin L, Johnson RK (2016) Strong landuse effects on the dispersal patterns of adult stream insects: implications for transfers of aquatic subsidies to terrestrial consumers. Freshw Biol 61:848-861

Collier KJ, Bury S, Gibbs M (2002) A stable isotope study of linkages between stream and terrestrial food webs through spider predation. Freshw Biol 47:1651-1659

Delong MD, Brusven MA (1998) Macroinvertebrate community structure along the longitudinal gradient of an agriculturally impacted stream. Environ Manage 22:445-457

Dreyer J, Hoekman D, Gratton C (2012) Lake-derived midges increase abundance of shoreline terrestrial arthropods via multiple trophic pathways. Oikos 121:252-258

Duong TM, Gomez AB, Sherratt TN (2017) Response of adult dragonflies to artificial prey of different size and colour. PLoS One 12: 0179483

Frainer A, McKie BG (2015) Shifts in the diversity and composition of consumer traits constrain the effects of land use on stream ecosystem functioning. Adv Ecol Res 52:169-200

Frainer A, McKie BG, Malmqvist B (2014) When does diversity matter? Species functional diversity and ecosystem functioning across habitats and seasons in a field experiment. J Anim Ecol 83:460-469

Frainer A, Polvi LE, Jansson R, McKie BG (2018) Enhanced ecosystem functioning following stream restoration: the roles of habitat heterogeneity and invertebrate species traits. J Appl Ecol $55: 377-385$

Fukui D, Murakami M, Nakano S, Aoi T (2006) Effect of emergent aquatic insects on bat foraging in a riparian forest. J Anim Ecol $75: 1252-1258$ 
Gladyshev MI, Arts MT, Sushchik NN (2009). Preliminary estimates of the export of omega-3 highly unsaturated fatty acids (EPA + DHA) from aquatic to terrestrial ecosystems. In: Kains M, Brett MT, Arts MT (eds) Lipids in aquatic ecosystems. Springer, New York: pp 179-210

Göthe E, Angeler DG, Sandin L (2013) Metacommunity structure in a small boreal stream network. J Anim Ecol 82:449-458

Gratton C, Vander Zanden MJ (2009) Flux of aquatic insect productivity to land: comparison of lentic and lotic ecosystems. Ecology 90:2689-2699

Gratton C, Donaldson J, Vander Zanden MJ (2008) Ecosystem linkages between lakes and the surrounding terrestrial landscape in northeast Iceland. Ecosystems 11:764-774

Gray LJ (1993). Response of insectivorous birds to emerging aquatic insects in riparian habitats of a tallgrass prairie stream. Am Midl Nat 129:288-300

Greenwood MJ, Booker DJ (2016) Influence of hydrological regime and land cover on traits and potential export capacity of adult aquatic insects from river channels. Oecologia 180:551-566

Greenwood MJ, McIntosh AR (2008) Flooding impacts on responses of a riparian consumer to cross-ecosystem subsidies. Ecology 89:1489-1496

Harding J, Young RG, Hayes J, Shearer KA, Stark J (1999) Changes in agricultural intensity and river health along a river continuum. Freshw Biol 42:345-357

Hoekman D, Dreyer J, Jackson RD, Townsend PA, Gratton C (2011) Lake to land subsidies: experimental addition of aquatic insects increases terrestrial arthropod densities. Ecology 92:2063-2072

Jonsson M, Deleu P, Malmqvist B (2013) Persisting effects of river regulation on emergent aquatic insects and terrestrial invertebrates in upland forests. River Res Appl 29:537-547

Kautza A, Sullivan MP (2015) Shifts in reciprocal river-riparian arthropod fluxes along an urban-rural landscape gradient. Freshw Biol 60:2156-2168

Kovats Z, Ciborowski J, Corkum L (1996) Inland dispersal of adult aquatic insects. Freshw Biol 36:265-276

Krosch MN, Baker AM, Mckie BG, Mather PB, Cranston PS (2009) Deeply divergent mitochondrial lineages reveal patterns of local endemism in chironomids of the Australian Wet Tropics. Austral Ecol 34:317-328

Kupilas B, Friberg N, McKie BG, Jochmann MA, Lorenz AW, Hering D (2016) River restoration and the trophic structure of benthic invertebrate communities across 16 European restoration projects. Hydrobiologia 769:105-120

Lamberti GA, Chaloner DT, Hershey AE (2010) Linkages among aquatic ecosystems. J N Am Benthol Soc 29:245-263

Lassen SB, Nielsen SA, Kristensen M (2012) Identity and diversity of blood meal hosts of biting midges (Diptera: Ceratopogonidae: Culicoides Latreille) in Denmark. Parasit Vectors 5:143

Leopold LB, Wolman MG, Miller JP (1964). Fluvial processes in geomorphology. Freeman and Company, New York

Logan P, Brooker MP (1983) The macroinvertebrate faunas of riffles and pools. Water Res 17:263-270

Malmqvist B (2002) Aquatic invertebrates in riverine landscapes. Freshw Biol 47:679-694

Malmqvist B, Adler PH, Kuusela K, Merritt RW, Wotton RS (2004). Black flies in the boreal biome, key organisms in both terrestrial and aquatic environments: a review. Ecoscience 11:187-200

Marczak LB, Richardson JS (2008) Growth and development rates in a riparian spider are altered by asynchrony between the timing and amount of a resource subsidy. Oecologia 156:249-258

Marczak LB, Thompson RD, Richardson JS (2007) Meta-analysis: trophic level, habitat, and productivity shape the food web effects of resource subsidies. Ecology 88:140-148
McCreadie JW, Adler PH (2012) The roles of abiotic factors, dispersal, and species interactions in structuring stream assemblages of black flies (Diptera: Simuliidae). Aquat Biosyst 8:14-14

Moldenke AR, Linden CV (2007) Effects of clearcutting and riparian buffers on the yield of adult aquatic macroinvertebrates from headwater streams. For Sci 53:308-319

Moore JW, Schindler DE (2010) Spawning salmon and the phenology of emergence in stream insects. Proc R Soc B Biol Sci 277:1695-1703

Muehlbauer JD, Collins SF, Doyle MW, Tockner K (2014) How wide is a stream? Spatial extent of the potential "stream signature" in terrestrial food webs using meta-analysis. Ecology 95:44-55

Myrdal J, Morell M (eds) (2011) The Agrarian history of Sweden: from 4000 BC to AD 2000. Nordic Academic Press, Lund

Nakano S, Murakami M (2001) Reciprocal subsidies: dynamic interdependence between terrestrial and aquatic food webs. Proc Natl Acad Sci USA 98:166-170

Oksanen J, Blanchet FG, Kindt R, Legendre P, Minchin PR, O'hara R, Simpson GL, Solymos P, Stevens MHH, Wagner H (2013) Package 'vegan'. Community ecology package, version 2

Petchey OL, Gaston KJ (2006) Functional diversity: back to basics and looking forward. Ecol Lett 9:741-758

Petersen RC (1992) The Rce-a Riparian, channel, and environmental inventory for small streams in the agricultural landscape. Freshw Biol 27:295-306

Petersen I, Masters Z, Hildrew A, Ormerod SJ (2004) Dispersal of adult aquatic insects in catchments of differing land use. J Appl Ecol 41:934-950

Poff NL, Olden JD, Vieira NK, Finn DS, Simmons MP, Kondratieff BC (2006) Functional trait niches of North American lotic insects: traits-based ecological applications in light of phylogenetic relationships. J N Am Benthol Soc 25:730-755

Polis GA, Anderson WB, Holt RD (1997) Toward an integration of landscape and food web ecology: the dynamics of spatially subsidized food webs. Annu Rev Ecol Syst 28:289-316

Poulin B, Lefebvre G, Paz L (2010) Red flag for green spray: adverse trophic effects of Bti on breeding birds. J Appl Ecol 47:884-889

Quinn, GP, Keough MJ (2002) Experimental Design and Data Analysis for Biologists. Cambridge University Press, Cambridge, UK pp. 537

Reich P, Wright I, Cavender-Bares J, Craine J, Oleksyn J, Westoby M, Walters M (2003) The evolution of plant functional variation: traits, spectra, and strategies. Int J Plant Sci 164:S143-S164

Rosenfeld JS, Hudson JJ (1997) Primary production, bacterial production and invertebrate biomass in pools and riffles in southern Ontario streams. Archiv für Hydrobiol 139:301-316

Sato T, El-Sabaawi RW, Campbell K, Ohta T, Richardson JS (2016) A test of the effects of timing of a pulsed resource subsidy on stream ecosystems. J Anim Ecol 85:1136-1146

Statzner B, Béche LA (2010) Can biological invertebrate traits resolve effects of multiple stressors on running water ecosystems? Freshw Biol 55:80-119

Stenroth K, Polvi LE, Fältström E, Jonsson M (2015) Land-use effects on terrestrial consumers through changed size structure of aquatic insects. Freshw Biol 60:136-149

Strasevicius D, Jonsson M, Nyholm NEI, Malmqvist B (2013) Reduced breeding success of Pied Flycatchers Ficedula hypoleuca along regulated rivers. Ibis 155:348-356

Tockner K, Pennetzdorfer D, Reiner N, Schiemer F, Ward J (1999) Hydrological connectivity, and the exchange of organic matter and nutrients in a dynamic river-floodplain system (Danube, Austria). Freshw Biol 41:521-535

Tokeshi M (1994) Life cycles and population dynamics. In: Armitage P, Cranston PS, Pinder LCV (eds) Chironomidae: biology and ecology of non-biting midges. Chapman and Hall, London, pp 225-268 
Torres-Ruiz M, Wehr JD (2010) Changes in the nutritional quality of decaying leaf litter in a stream based on fatty acid content. Hydrobiologia 651:265-278

Truchy A, Angeler DG, Sponseller RA, Johnson RK, McKie BG (2015) Linking biodiversity, ecosystem functioning and services, and ecological resilience: towards an integrative framework for improved management. Adv Ecol Res 53:55-96

Uesugi A, Murakami M (2007) Do seasonally fluctuating aquatic subsidies influence the distribution pattern of birds between riparian and upland forests? Ecol Res 22:274-281

Verberk WC, Siepel H, Esselink H (2008) Life-history strategies in freshwater macroinvertebrates. Freshw Biol 53:1722-1738

Wesner JS (2010) Seasonal variation in the trophic structure of a spatial prey subsidy linking aquatic and terrestrial food webs: adult aquatic insects. Oikos 119:170-178
Woodward G, Gessner MO, Giller PS, Gulis V, Hladyz S, Lecerf A, Malmqvist B, McKie BG, Tiegs SD, Cariss H, Dobson M, Elosegi A, Ferreira V, Graca MAS, Fleituch T, Lacoursiere JO, Nistorescu M, Pozo J, Risnoveanu G, Schindler M, Vadineanu A, Vought LBM, Chauvet E (2012) Continental-scale effects of nutrient pollution on stream ecosystem functioning. Science 336:1438-1440

Worischka S, Schmidt SI, Hellmann C, Winkelmann C (2015) Selective predation by benthivorous fish on stream macroinvertebrates- the role of prey traits and prey abundance. Limnol Ecol Manag Inland Waters 52:41-50 